\title{
GRIN2B Gene
}

National Cancer Institute

\section{Source}

National Cancer Institute. GRIN2B Gene. NCI Thesaurus. Code C102458.

This gene plays a role in both neurotransmitter binding and ion transport. 